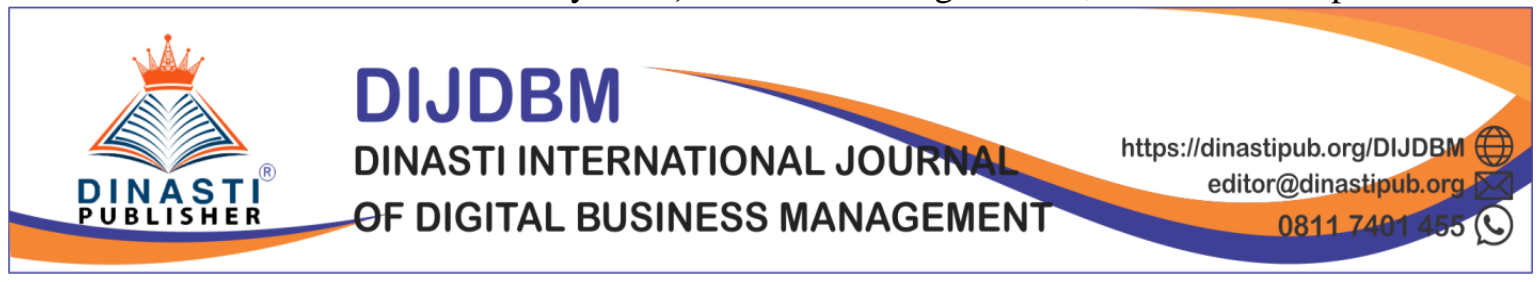

\title{
THE EFFECT OF A SITUATIONAL LEADERSHIP STYLE AND THE APPLICATION OF ACCOUNTING INFORMATION SYSTEMS TO FRAUD ON VILLAGE FUND MANAGEMENT IN TANGERANG DISTRICT
}

\author{
Tubagus Yudha Brata ${ }^{1)}$ \\ ${ }^{1)}$ Departement of Accounting, Mercubuana University, Jakarta, Indonesia, yudhibakti@gmail.com
}

\section{Corresponding author: Tubagus Yudha Brata}

\begin{abstract}
This study is motivated by the many cases of corruption, especially when the management of village funds began to be implemented. This type of quantitative research with survey techniques using closed questionnaire 5 Likert scale choices. Affordable population 224 people. A sample of 90 people was taken by simple random sampling. The results showed: 1) Situational leadership style in the Good category. 2) Application of AIS in the Good category. 3) Management of village funds has the potential to cause fraud. 4) Situational leadership style has a significant effect on fraud with a negative correlation that is if the situational leadership style increases, the potential for fraud decreases. 5) The application of SIA has a significant effect on Fraud, with a negative correlation that is if the application of AIS is high, the potential for fraud is reduced. 6) Situational leadership style and application of AIS together influence fraud.
\end{abstract}

Keywords: Situational Leadership Style, AIS, Fraud

\section{INTRODUCTION}

A study on the trend of corruption cases in the 2018 period shows that the phenomenon of corruption in the regions has become more widespread after the implementation of village fund allocations, although when compared to the budget provided by the government, the state losses are relatively small, but this indicates that corruption has occurred at the lowest level of government, namely the village which in practice takes refuge behind the concept of participation. Supervision of village funds is regulated by Law no. 6 of 2014, but not yet fully implemented, this is indicated by many problems in the management of village funds. Does leadership style have an influence on cheating? Does the application of the Accounting Information System have an influence on fraud? Does the leadership style and the 
implementation of the Accounting Information System simultaneously have an influence on fraud?

\section{LITERATURE REVIEW}

\section{Fraud}

In simple terms, fraud is defined as an act of fraud, including lying, stealing, fabricating and embezzling those committed by people inside and or outside the organization with the intention of obtaining personal or group benefits.

Many theories put forward the factors that cause cheating, including the Fraud Triangle theory developed by Cressey which states that cheating is caused by pressure / encouragement, opportunity, and justification. Among these 3 factors, the opportunity factor is most likely to be minimized through the application of good processes, transparent financial implementation procedures, control and early detection of problems that occur.

Fraud in this study is measured to be limited to the act of cheating in the dimension of Diamond Fraud, namely: 1) Pressure; 2) Opportunity; 3) Rationalization (Rationalization); 4) Capability.

\section{Accounting Information Systems (AIS)}

Azhar Susanto (2017: 72) defines SIA as a collection of physical and non-physical subsystems that are interconnected and work together harmoniously to process transaction data related to financial issues into financial information.

Azhar Susanto (2017: 8) states that the accounting information system is built with the main objective: "processing financial data from various sources into accounting information required by various kinds of assessments".

Romney and Steinbart (2015: 11) suggest that the components of the Accounting Information System consist of: 1) People who use the system; 2) Procedures and instructions used; 3) Data regarding organizations and business activities; 4) accounting data processing software; 4) Information technology infrastructure; 5) Internal control and security measures.

The implementation of SIA is measured from the dimensions according to the opinion of Azhar Susanto (2017: 207), namely: 1) Hardware; 2) Software (Software); 3) Otrak Device (Brainware); 4) Procedure; 5) Database 6) Communication Network

\section{Leadership Style}

According to Stoner (2017: 58) leadership tasks include: 1) making decisions; 2) developing the imagination of subordinates; 3 ) develop follower loyalty; 4) initiator, activation and control of the plan; 5) Utilizing human resources and other resources; 6) Controlling and making improvements to subordinates' mistakes; 7) Give awards; 8) Delegating authority to subordinates; 8) implementation of decisions. 
Gary Yukl (2015: 65) states that there are 14 principles of leadership behavior, namely: 1) Planning and organizing (planning and organizing); 2) Troubleshooting (problem solving); 3) Explaining roles and objectives (clarifying roles and objectifies); 4) Providing information (informing); 5) Monitoring (monitoring); 6) Motivating and inspiring (motivating and inspiring); 7) Consulting (consulting); 8) Delegating (delegating); 9) Provide support (supporting); 10) Developing and guiding (developing and mentoring); 11) Managing conflict and team (managing and team building); 12) Building a network (networking); 13) Recognizing; and 14) Giving gifts (rewarding). The leadership style of each leader tends to differ from situation to situation. Situational leadership style suggests that effective leader behavior must always pay attention to the situation at hand, and treat subordinates according to their respective needs.

Measurement of leadership style in this study is taken from several indicators developed from several dimensions, namely: 1) Leaders' directions and directions; 2) leadership relationship behavior; 3 ) readiness level of followers.

\section{RESEARCH METHODS}

The research was conducted in Tangerang Regency. The study population was 224 people. Samples were taken for research purposes as much as $40 \%$ of the population or as many as 90 people randomly. The data analysis method used is descriptive correlational.

\section{FINDING AND DISCUSSION}

\section{General Description}

The leadership style applied in the Tangerang district government has worked well. The implementation of SIA in the Tangerang Regency Government is in the good category and the management of village funds in the Tangerang district government is in the category of potential fraud.

\section{Data Analysis}


Table 1. Correlation

\begin{tabular}{|l|l|r|r|r|}
\hline \multirow{2}{*}{$\begin{array}{l}\text { Leadership } \\
\text { style }\end{array}$} & Pearson Correlation & \multicolumn{1}{c|}{$\begin{array}{c}\text { Leadership } \\
\text { style }\end{array}$} & $\begin{array}{c}\text { Implementatio } \\
\text { n of AIS }\end{array}$ & \multicolumn{1}{c|}{ Fraud } \\
\cline { 2 - 5 } & Sig. (2-tailed) & 1 & $0.830^{* *}$ & $-0.771^{* *}$ \\
\cline { 2 - 5 } & $\mathrm{N}$ & 90 & 0.000 & 0.000 \\
\hline \multirow{2}{*}{$\begin{array}{l}\text { Implementati } \\
\text { on of AIS }\end{array}$} & Pearson Correlation & $0.830^{* *}$ & 90 & 90 \\
\cline { 2 - 5 } & Sig. (2-tailed) & 0.000 & 1 & $-0.827^{* *}$ \\
\cline { 2 - 5 } & $\mathrm{N}$ & 90 & 90 & 0.000 \\
\hline \multirow{2}{*}{ Fraud } & Pearson Correlation & $-.771^{* *}$ & $-0.827^{* *}$ & 90 \\
\cline { 2 - 5 } & Sig. (2-tailed) & 0.000 & 0.000 & 1 \\
\cline { 2 - 5 } & $\mathrm{N}$ & 90 & 90 & 90 \\
\hline
\end{tabular}

**. Correlation is significant at the 0.01 level (2-tailed).

Table 2. Determination Coefficient

\begin{tabular}{|c|r|r|r|r|}
\hline Model & $\mathrm{R}$ & R Square & Adjusted R Square & Std. Error of the Estimate \\
\hline 1 & $0,845^{\mathrm{a}}$ & 0.715 & .708 & 1.649 \\
\hline
\end{tabular}

a. Predictors: (Constant), Implementasi SIA, Gaya Kepemimpinan

b. Dependent Variable: Fraud

Table 3. Multiple Regression

\begin{tabular}{|c|c|c|c|c|c|c|}
\hline \multirow[t]{2}{*}{ Model } & \multicolumn{3}{|c|}{ Unstandardized Coefficients } & \multirow{2}{*}{$\begin{array}{c}\begin{array}{c}\text { Standard } \\
\text { ized Coeff }\end{array} \\
\text { Beta }\end{array}$} & \multirow[t]{2}{*}{$\mathrm{t}$} & \multirow[t]{2}{*}{ Sig. } \\
\hline & \multicolumn{2}{|c|}{$\mathrm{B}$} & Std. Err & & & \\
\hline \multirow[t]{3}{*}{1} & (Constant) & 67.16 & 2.30 & & 29.18 & 0.000 \\
\hline & Leadership Style & -0.23 & 0.08 & -0.29 & -3.04 & 0.003 \\
\hline & AIS Implementation & -0.55 & 0.09 & -0.59 & -5.99 & 0.000 \\
\hline
\end{tabular}

a. Dependent Variable: Fraud

\section{Discussion}

The correlation coefficient between the variable leadership style and fraud is -0.771 at $\mathrm{df}=89$. Based on the criteria it can be seen that the sig. $<0.05$ so that the correlation that occurs between the Leadership Style variable and Fraud is a significant correlation in the reverse direction, meaning that if the Leadership Style increases, then Fraud decreases.

The correlation coefficient between the variable AIS application and fraud is -0.830 at $\mathrm{df}=89$. The value of sig. $<0.05$, so the correlation that occurs between the variable AIS application and fraud is a significant correlation. The $\mathrm{R}$ value obtained is 0.851 close to 
number 1, so the simultaneous correlation between Leadership Style and SIA Implementation with Fraud is in the very strong category.

Leadership style together with the implementation of SIA provides a relatively large and significant contribution to fraud. This is indicated by the acquisition of the value of $\mathrm{R}$ $\neg 2$ (coefficient of determination) $=0.716(71.6 \%)$, or $\bar{Y}=67.20+(-0.23 X 1)+(-$ $0.55 \times 2)$.

First hypothesis test: $\bar{Y}=-11.05+1.15 X 1$. This equation provides information that the addition of one leadership style score will be followed by a decrease in the score of 1.15 cheating. The correlation coefficient ( $r$ ) of 0.795 indicates a strong relationship or an index of determination of 0.630 , which means that $63 \%$ of leadership styles influence fraud, the rest is determined by other factors.

Second hypothesis test: $\bar{Y}=20.85+0.88 X 2$. This equation provides information that the addition of one score for the implementation of AIS will be followed by an increase in the score of fraud. The correlation coefficient (r) is 0.675 or the determination index is 0.456 , indicating that $45.6 \%$ of fraud is determined by the implementation of SIA, the rest determined by other factors.

Third hypothesis test: $\bar{Y}=67.17+(-0.24 \mathrm{X} 1)+(-0.55 \mathrm{X} 2)$. This equation provides information that the score of cheating will decrease 0.23 times if there is an addition of one leadership style score, and will decrease by 0.55 if there is an addition of one score for the application of SIA. $\mathrm{R}=0.845(84.5 \%)$ or with a contribution of $\mathrm{R} 2=0.715$ $(71.5 \%)$, the price of the correlation coefficient $(\mathrm{R})=0.845$ or the index of determination (R2) of $=0.715$ indicating that $71.5 \%$ fraud is determined collectively - the same by the leadership style and the application of AIS.

\section{CONCLUSION}

1. There is a direct and significant influence of leadership style on the potential for fraud.

2. There is a direct and significant effect of the implementation of SIA on potential acts of fraud.

3. Simultaneously there is a direct and significant influence on the implementation of AIS and transformational leadership styles on the potential for fraud.

\section{REFERENCES}

Danim, Sudarwan. 2014, Motivasi Kepemimpinan dan Efektivitas Kelompok, Jakarta: Rineka Cipta.

Hermino, Agustinus. 2016. Kepemimpinan Pendidikan di Era Globalisasi, Yogyakarta: Pustaka Pelajar.

J. Dubrin, Andrew. 2016. Leadership; Research, Finding and Skill (Terjemahan), Ed. $8^{\text {th }}$, US: Cengage Learning. 
James A, Hall dan Tommie Singleton, 2014, Audit Teknologi Informasi dan Assurance, Buku Satu, Edisi Keempat, terjemahan Fitriasari, Jakarta: Salemba Empat.

Jogiyanto, 2015, Analisis dan Rancangan Sistem Informasi: pendekatan terstruktur teori dan praktek aplikasi bisnis. Yogyakarta: Andi Offset

Krismiaji, 2017, Sistem Informasi Akuntansi, Eds. Yogyakarta: Pustaka Pelajar Official

Mardi, 2015, Sistem Informasi Akuntansi, cetakan kedua, Jakarta: Ghalia Indonesia.

Marno dan Triyo Supriyanto, 2014, Manajemen dan Kepemimpinan Pendidikan Islam, Cetakan II, Jakarta: Refika Aditama

Marsal B. Romney and Paul John Stainbart, 2015, Sistem Informasi Akuntansi, Edisi 13. Jakarta: Salemba Empat.

Mulyadi, 2016, Sistem Akuntansi, Edisi 8 Jilid 1, Jakarta: Salemba Empat.

Nawawi, Hadari. 2017. Evaluasi dan manajemen Kinerja di Lingkungan Perusahaan dan Industri, Cetakan kedua, Yogyakarta: Gadjah Mada University Press.

Rama Dasaratha and Frederick L. Jones, 2015, Sistem Informasi Akuntansi; Buku 1, Edisi empat, Jakarta: Salemba Empat

Robbin, Stepphen. \& Timothy A. Judge, 2015, Perilaku Organisasi, Edisi Enambelas, Jakarta: Salemba Empat.

Salman S., H.R. Otje dan Anthon F. Susanto, 2015, Teori Hukum; mengingat, mengumpulkan dan membuka kembali, Cetakan ke 8, Bandung: Refika Aditama.

Stoner, James A.F. dan R. Edward Freeman - Daniel R. Gilbert JR, 2017, Manajement, Edisi Bahasa Indonesia Jilid 2, Jakarta: Intermedia

Susanto, Azhar. 2017. Sistem Informasi Akuntansi; Pemahaman Konsep Secara Terpadu, Bandung: Lingga Jaya.

Yukl, Gary Yukl. 2015, Kepemimpinan dalam organisasi, Edisi Ketujuh, Jakarta: Indeks. 